\title{
The slow advance of a calving glacier: Hubbard Glacier, Alaska, U.S.A.
}

\author{
Dennis G. TRABAnT, ${ }^{1}$ Robert M. KRIMmel, ${ }^{2}$ Keith A. EGHELmeYeR, ${ }^{3}$ \\ SANDRA L. ZIRNHELD, ${ }^{3}$ DANiEl H. ELSBERG ${ }^{3}$ \\ ${ }^{1}$ U.S. Geological Survey, Department of the Interior, P.O. Box 757300, Fairbanks, AK 99775-7320, U.S.A. \\ E-mail:dtrabant@usgs.gov \\ ${ }^{2}$ U.S. Geological Survey, 1201 Pacific Avenue, Suite 600, Tacoma, WA 98402, U.S.A. \\ ${ }^{3}$ Geophysical Institute, University of Alaska, 903 Koyukuk Drive, Fairbanks, AK 99775-7320, U.S.A.
}

\begin{abstract}
Hubbard Glacier is the largest tidewater glacier in North America. In contrast to most glaciers in Alaska and northwestern Canada, Hubbard Glacier thickened and advanced during the 20th century. This atypical behavior is an important example of how insensitive to climate a glacier can become during parts of the calving glacier cycle. As this glacier continues to advance, it will close the seaward entrance to $50 \mathrm{~km}$ long Russell Fjord and create a glacier-dammed, brackish-water lake. This paper describes measured changes in ice thickness, ice speed, terminus advance and fjord bathymetry of Hubbard Glacier, as determined from airborne laser altimetry, aerial photogrammetry, satellite imagery and bathymetric measurements. The data show that the lower regions of the glacier have thickened by as much as $83 \mathrm{~m}$ in the last 41 years, while the entire glacier increased in volume by $14.1 \mathrm{~km}^{3}$. Ice speeds are generally decreasing near the calving face from a high of $16.5 \mathrm{~m} \mathrm{~d}^{-1}$ in 1948 to $11.5 \mathrm{~m} \mathrm{~d}^{-1}$ in 2001 . The calving terminus advanced at an average rate of about $16 \mathrm{~m} \mathrm{a}^{-1}$ between 1895 and 1948 and accelerated to $32 \mathrm{~m} \mathrm{a}^{-1}$ since 1948. However, since 1986, the advance of the part of the terminus in Disenchantment Bay has slowed to $28 \mathrm{~m} \mathrm{a}^{-1}$. Bathymetric data from the lee slope of the submarine terminal moraine show that between 1978 and 1999 the moraine advanced at an average rate of $32 \mathrm{~m} \mathrm{a}^{-1}$, which is the same as that of the calving face.
\end{abstract}

\section{INTRODUCTION}

Hubbard Glacier, the largest calving glacier on the North American continent, has been advancing since it was first mapped by the International Boundary Commission in 1895 (Davidson, 1903). The advance has been slow but persistent, amounting to $2.5 \mathrm{~km}$ since 1895 , and has occurred during a period when most other glaciers in Alaska and northwestern Canada have thinned and retreated (e.g. Arendt and others, 2002). This atypical behavior is the theoretically predicted consequence of being in the advance phase of the calving glacier cycle. The calving glacier cycle was described by Post (1975, 1980a, b, c, d) as an explanation for the alternating slow advances and rapid retreats that have persisted throughout the middle and late Holocene of nearly all of Alaska's calving glaciers. Here we discuss recent investigations of this calving glacier that document its anomalous advance and indifference to the global changes that are causing most glaciers to lose mass rapidly and retreat.

\section{BAGKGROUND}

Hubbard Glacier is currently about $123 \mathrm{~km}$ long, with a calving face that is $11.4 \mathrm{~km}$ in width and, seasonally, as high as $100 \mathrm{~m}$ a.s.l. Ice radar thickness measurements in August 1986 (Mayo, 1989; Trabant and others, 1991) showed that the glacier bed reaches as deep as $414 \mathrm{~m}$ below sea level about $1.5 \mathrm{~km}$ upstream from the terminus.
Hubbard Glacier has a long documented history. It filled all of Yakutat Bay (Fig. 1) in about AD1130 (Plafker and Miller, 1958). Russell (1891) and Gilbert (1904), interpreting records of the visits by A. Malaspina in 1792 and G. Vancouver in 1794, place the terminus of Hubbard Glacier south of Haenke Island (Fig. 1); this implies a 660 year retreat that averaged about $80 \mathrm{~m} \mathrm{a}^{-1}$. Tarr and Martin (1914) report that Russian maps dating from the early 1800s show the terminus just north of Haenke Island and a lake in the Russell Fjord basin. The oral history of the Tlingit Indians of Yakutat includes a description of the emptying of the lake in Russell Fjord about 1860 (de Laguna, 1972). Russell's (1891) map shows the terminus about $2 \mathrm{~km}$ north of Osier Island. The retreat between 1794 and 1891 also averaged about $80 \mathrm{~m} \mathrm{a}^{-1}$. During his second visit, Russell (1893) recognized that the fjord, which was later named for him, had been a glacier-dammed lake. The first surveyed position of the terminus of Hubbard Glacier was produced by the International Boundary Commission in 1895 (Davidson, 1903). Most of the 20th-century literature is cited in Mayo (1988) and Trabant and others (1991).

\section{THE GALVING GLAGIER GYGLE}

Post (1975) described the processes that control the advance and retreat cycles of calving temperate glaciers. The original description has been augmented by Trabant and others (1991), Motyka and Post (1995) and Post and Motyka (1995). The tenets of the hypothesis are that: (1) the primary factor 


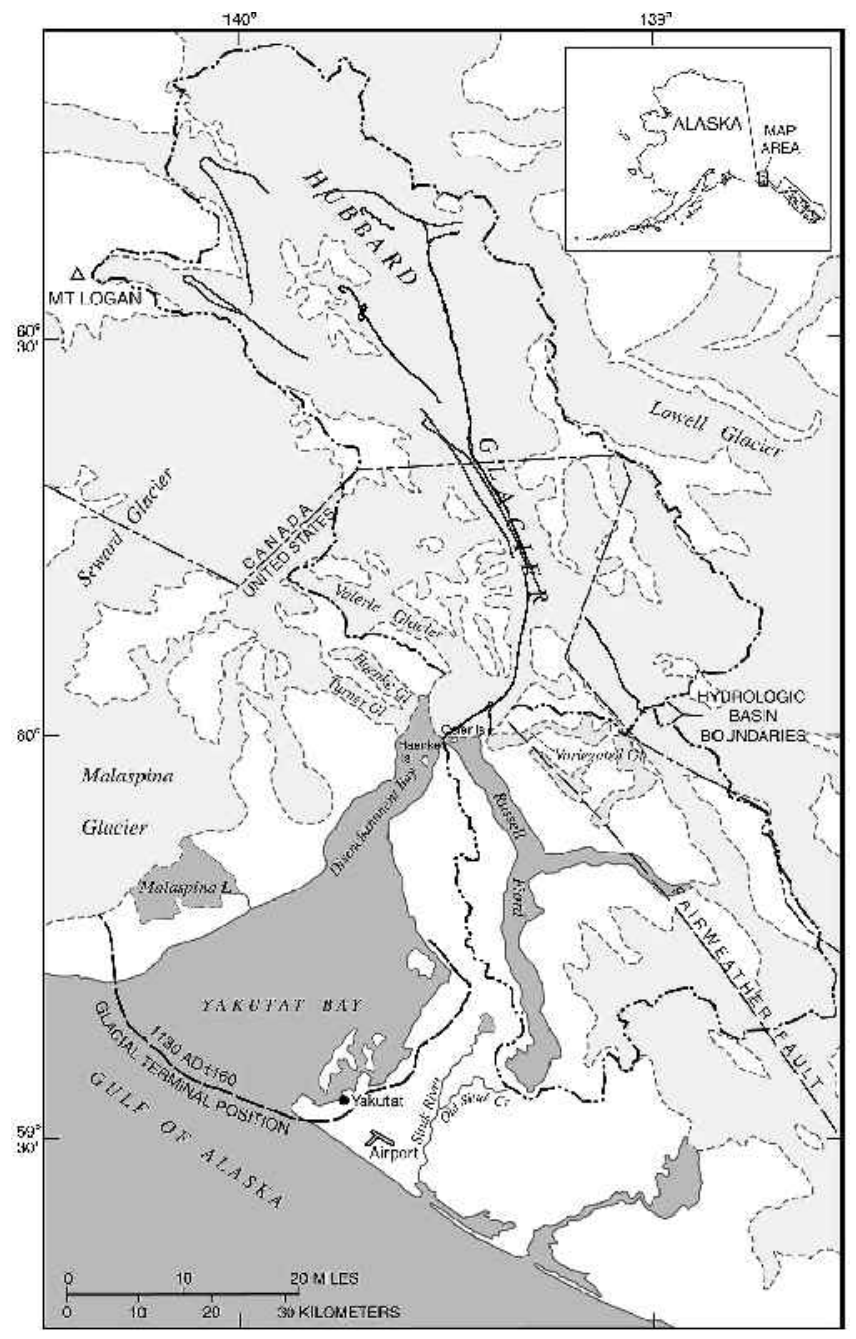

Fig. 1. Hubbard Glacier study area. The lines on Hubbard Glacier are the airborne laser profiles flown on 2 May 2000 and 6 June 2001.

that influences the advance and retreat of temperate calving glaciers is the water depth at the calving face; (2) the cycling is not directly related to climate, except perhaps for the initiation of retreat; and (3) the advance and retreat cycling will continue as long as the glacier continues to calve.

Calving glaciers advance by moving their terminal moraines down the fjords in which they calve. In all known cases, advancing calving glaciers end on terminal moraine shoals that nearly fill the fjord at the calving front (Brown and others, 1982). The rate of advance is rarely more than a few tens of meters per year. In general, calving glaciers advance until the losses due to melting approach the mass flux out of the accumulation area and calving losses cannot be replaced. In terms of the accumulation-area ratio (AAR), calving glaciers reach mass flux equilibrium when the AAR approaches an empirical value of about 0.7 (Post and Motyka, 1995). The AAR of Columbia Glacier was 0.66 when it began its irreversible retreat (Trabant and others, 1991).

Calving glaciers retreat when, for any reason, the calving face retreats into the deeper water behind its terminal moraine shoal. Because calving speed increases rapidly with water depth, the increasing calving flux soon exceeds the mass flux out of the accumulation area, and an irreversible retreat begins. The rate of retreat often approaches $100 \mathrm{~m} \mathrm{a}^{-1}$. Hubbard Glacier retreated at an average rate of $80 \mathrm{ma}^{-1}$ between 1130 and 1891 .

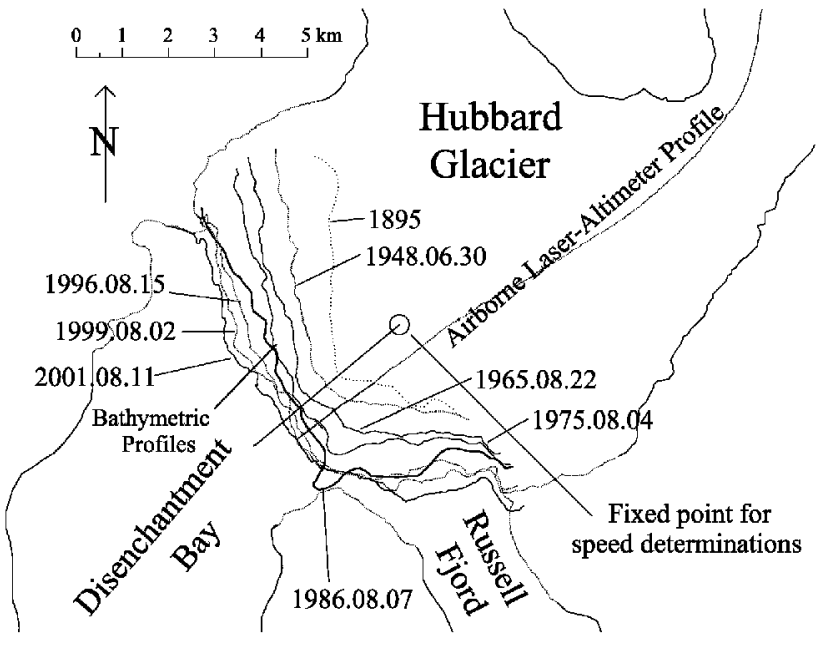

Fig. 2. Terminus locations of Hubbard Glacier since 1895. The flow-parallel line is the ground-track of the airborne laser profile. The circle is the "fixed location" used for interpolating glacier surface speed, and the ray attached to the circle was used to define the "near-terminus" ice speeds in Figure 5.

\section{REGENT BEHAVIOR OF HUBBARD GLAGIER}

Hubbard Glacier, with an AAR of approximately 0.95, is in the strong, early part of the advancing phase of the calving glacier cycle. Soon, Hubbard Glacier will advance entirely across the seaward entrance to Russell Fjord (Fig. 1), probably turning it into a glacier-dammed lake. Russell Lake will fill with fresh water from the many streams in the hydrologic basin until the lake overflows the low divide (about $40 \mathrm{~m}$ a.s.l.) at the southeastern end of the basin. Russell Lake will then be a feature in Alaska's geography until it is released during the next retreat cycle of Hubbard Glacier.

A harbinger dam was formed during 1986 (Fig. 2). Abundant sediments and shoaling near the entrance to Russell Fjord almost eliminated calving along a small part of the calving face, and increased ice speeds from a pulse in the flow of Hubbard Glacier combined to allow a small part of the terminus to advance rapidly and form a temporary ice and push-moraine dam. (Two episodes of flow instability in Hubbard Glacier (1986 and 1989) have been documented by Trabant and others (1991).) After the entrance was blocked, runoff from the hydrologic basin raised the water level in Russell Lake to $25.5 \mathrm{~m}$ a.s.l. (Seitz and others, 1986) before the dam failed in October 1986 (Mayo, 1989).

During June 2002, Hubbard Glacier again pushed glacialmarine sediments into the entrance to Russell Fjord until they rose above sea level and blocked the entrance. A squeeze-push moraine, which emerged between the advancing glacier ice and bedrock, effectively blocked the entrance during late June. The water level in the cut-off fjord rose at an average rate of $0.2 \mathrm{md}^{-1}$ and was controlled by the rising moraine dam. Water continued to overflow the moraine until near the end of July 2002. A maximum level of $18.6 \mathrm{~m}$ a.s.l. was attained during 14 August. This followed a 30 hour, $140 \mathrm{~mm}$ rainstorm which caused an unusually rapid rise of lake level and increased the volume of water overflowing and eroding the moraine. An outburst flood commenced which reached a maximum discharge of about $54000 \mathrm{~m}^{3} \mathrm{~s}^{-1}$ at about midnight of 14 August. By the afternoon of 15 August the moraine dam had been completely removed, the lake emptied, and tidal exchange had resumed in Russell Fjord. 


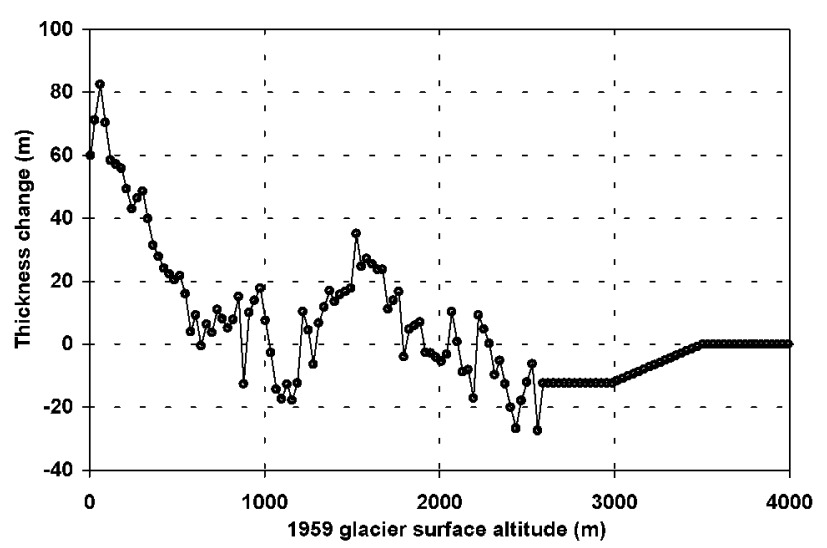

Fig. 3. Change in surface altitude, 1959-2000, vs 1959 glacier surface altitude. The changes were determined along the airborne laser-altimetry profiles shown in Figure 1. Data were extrapolated above $2560 \mathrm{~m}$ as described in the text.

\section{ICE-THICKNESS CHANGES}

The positive glacier-wide mass balance of Hubbard Glacier is directly measurable as changes in the overall surface altitude (thickness). These changes were measured using an airborne laser altimeter system that has been described by Echelmeyer and others (1996). The resulting surface profiles have data points every $1.5 \mathrm{~m}$ along the flight path, and a vertical accuracy of about $0.3 \mathrm{~m}$. Several profiles were flown on 2 May 2000, and the main profile was remeasured on 6 June 2001 (Fig. 1). The year 2000 profiles extended from the terminus to near the head of the glacier at an altitude of about $2600 \mathrm{~m}$. These data were compared to topographic maps compiled from 1959 aerial photography in the U.S.A. and 1976 photography in Canada (Fig. 3). (Note: the 1959 U.S. Geological Survey (USGS) maps are unpublished, but they were found to be more accurate than the published maps that were compiled from 1961 photography.) The U.S.-Canadian border is at about $1300 \mathrm{~m}$ altitude on Hubbard Glacier (Fig. 1). It is believed that most of the errors in the derived thickness changes are related to vertical errors on the maps. Above $2560 \mathrm{~m}$ altitude, thickness changes were extrapolated by assuming a constant value of $-12.3 \mathrm{~m}$ (the average measured altitude change at $2560 \mathrm{~m}$ altitude) up to an altitude of $2990 \mathrm{~m}$. Above $2990 \mathrm{~m}$, the altitude change was linearly extrapolated to zero at $3500 \mathrm{~m}$ and then held constant at zero to the top of the basin at $4600 \mathrm{~m}$. Extrapolation from the profile data to a glacier volume change followed methods described by Echelmeyer and others (1996) and Arendt and others (2002). The glacier volume change between 1959 and 2000 (with the necessary extrapolation of the 1976-2000 altitude changes from the Canadian map comparisons) was positive, with a total volume increase of $14.1 \mathrm{~km}^{3}$ at an average rate of $0.3 \mathrm{~km}^{3} \mathrm{a}^{-1}$. This corresponds to a glacier-wide average rate of thickening of about $0.1 \mathrm{ma}^{-1}$ during the 41 year period. The measured distribution of thickness change above sea level was somewhat irregular, ranging from a thickening of $120 \mathrm{~m}\left(2.9 \mathrm{~m} \mathrm{a}^{-1}\right)$ near the terminus to a thinning of $27 \mathrm{~m}\left(0.7 \mathrm{~m} \mathrm{a}^{-1}\right)$ at about $2560 \mathrm{~m}$ altitude (Fig. 3). Most of the positive volume change occurred in the lower accumulation area between 1200 and $1800 \mathrm{~m}$ altitude. The second largest area of growth was below $300 \mathrm{~m}$ altitude in the terminal lobe. About one-seventh of the total volume increase is the growing ice volume stored below sea level as

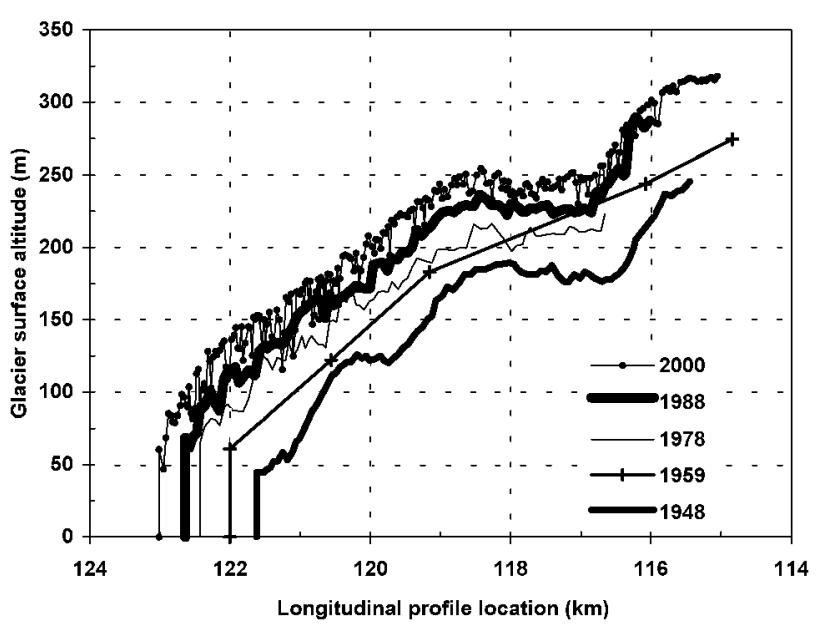

Fig. 4. Longitudinal profiles of the terminal lobe of Hubbard Glacier. The 2000 profile is from the airborne laser profiling system. The 1959 profile is taken from the published USGS Mount Saint Elias 1:250 000-scale quadrangle. The others were photogrammetrically determined from aerial photography along the 2000 profile line. Some data are not shown for clarity. The errors in the data prior to 2000 are about $\pm 5 \mathrm{~m}$.

the terminus slowly advances. The subaqueous volume change has no net effect on sea level. An area of volume loss occurred between 2200 and $2600 \mathrm{~m}$ altitude. This pattern of thickness change is different from that measured on other glaciers in the region, where the norm is strong thinning at low altitudes and zero to slightly positive changes at higher altitudes (Arendt and others, 2002).

Comparing the 2000 and 2001 laser profiles for Hubbard Glacier reveals that thickening of the glacier is continuing at a rate of $0.8 \mathrm{~m} \mathrm{a}^{-1}$, about eight times faster than the average rate for the 41 year period. The areas of thickening and thinning were similar to those determined for the 41 year period, except that the area in which the largest volume increase occurred, in the lower part of the accumulation area, extended higher on the glacier, to about $1900 \mathrm{~m}$ altitude. This increased thickening corresponds to a generally less negative balance year observed in this region in 2000/ 01 (K. A. Echelmeyer, unpublished data).

A more complete sequence of glacier surface altitudes along the terminal lobe below about $250 \mathrm{~m}$ a.s.l. was determined from five sets of aerial photographs spanning the years 1948-99 (Fig. 4). The altitudes were determined photogrammetrically along the same track as the lower part of the airborne laser altimetry, and limited data from the contours on the unpublished 1959 map are included. The data (Fig. 4) show that the average thickening rates on the lower $6 \mathrm{~km}$ of the terminal lobe have decreased somewhat with time: from values of $+2.7 \mathrm{~m} \mathrm{a}^{-1}$ between 1948 and 1959 to $+2.1 \mathrm{~m} \mathrm{a}^{-1}$ between 1948 and 1978, +1.4 $\mathrm{m} \mathrm{a}^{-1}$ between 1959 and 1978, $+1.7 \mathrm{~m} \mathrm{a}^{-1}$ between 1978 and 1988, and $+1.4 \mathrm{~m} \mathrm{a}^{-1}$ between 1988 and 1999. The errors in the photogrammetric altitude profile determinations are about $\pm 5 \mathrm{~m}$. The profiles (Fig. 4) show that thickening increases toward the terminus, and that a substantial part of the volume increase in the ablation area is due to advance of the terminus.

\section{ICE SPEED}

Ice speeds on the lower $12 \mathrm{~km}$ of Hubbard Glacier were 


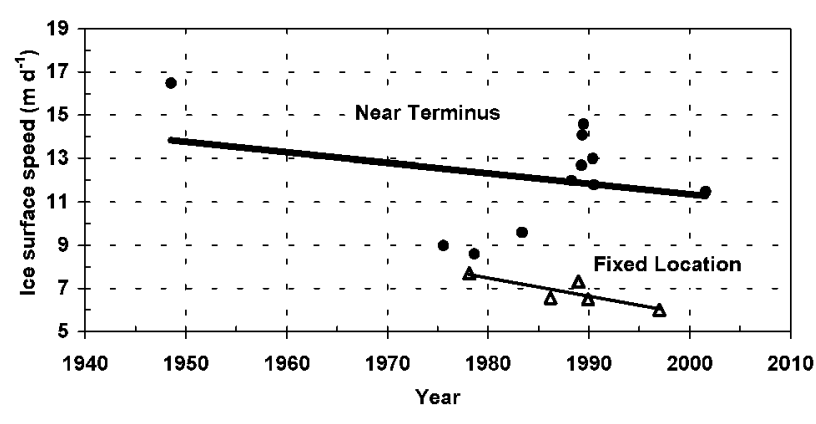

Fig. 5. Ice-surface speeds on Hubbard Glacier. The "fixed location" is about $3 \mathrm{~km}$ up-glacier from the 1997 terminus near the center of the glacier (Fig. 2). The linear rate of deceleration at the fixed location is about $0.08 \mathrm{md}^{-1} \mathrm{a}^{-1}$, and is affected by the changing strain as the distance to the calving face increases. The 11 "near-terminus"speeds were interpolated as close to the calving face as possible, along a flowline down-glacier from the fixed location (Fig. 2). The rate of deceleration of the nearterminus speeds is about $0.05 \mathrm{md}^{-1} \mathrm{a}^{-1}$.

photogrammetrically measured on 20 pairs of aerial photographs and 2 pairs of satellite images using analytical methods described by Krimmel (2001). The technique relies on repeated identification of seracs and crevasse patterns.

Because serac and crevasse patterns are targets of opportunity, there are rarely repeated measurements at any specific location on the glacier. For comparison purposes, 16 glacier surface speeds were interpolated to a fixed horizontal location (Fig. 2) about $3 \mathrm{~km}$ above the 1997 terminus near the center of the glacier. A second set of 11 speeds was interpolated as close to the calving face as possible along a flowline down-glacier from the fixed location (Fig. 2). This latter set of velocities corresponds to a moving location that follows the advancing terminus instead of a fixed location in space (the former set), where the ice is becoming thicker with time. Usually the maximum surface speeds on the terminal lobe occur close to the calving face near this flowline. Errors in speed determinations arise from the photogrammetric modelling process as well as from the repeated identification of targets that change with time. Vector endpoints are assumed to have relative absolute errors no larger than $\pm 20 \mathrm{~m}$. For periods that averaged 39 days, the error in speed determinations is estimated to be $\pm 0.6 \mathrm{~m} \mathrm{~d}^{-1}$.

Ice-surface speeds of the terminal lobe vary seasonally by as much as $2 \mathrm{~m} \mathrm{~d}^{-1}$. Seasonal speed variations were evaluated by calculating the average speed over a 365 day period by superposing all the measured speeds. The annual speed maximum is about $8.1 \mathrm{md}^{-1}$ and occurs in May and June; the minimum is about $6.7 \mathrm{~m} \mathrm{~d}^{-1}$ and occurs between September and November. Seasonal variability was removed from the speed data at the fixed location by selecting the speeds derived from the same season (winters) with periods of 9 months or longer (Fig. 5). The reduced dataset is limited, but appears to suggest a linear deceleration between 1978 and 1997 from $7.7 \mathrm{~m} \mathrm{~d}^{-1}$ to $6.0 \mathrm{~m} \mathrm{~d}^{-1}$. Part of this deceleration is due to decreasing surface strain at the fixed location, as the glacier increases in thickness at this location and the distance from the calving face increases with time. No correction for the influence of strain is possible because surface strain rates cannot be analyzed from the dataset.

The 11 surface ice speeds near the calving face also show a deceleration (about $0.05 \mathrm{~m} \mathrm{~d}^{-1} \mathrm{a}^{-1}$; Fig. 5). These are free

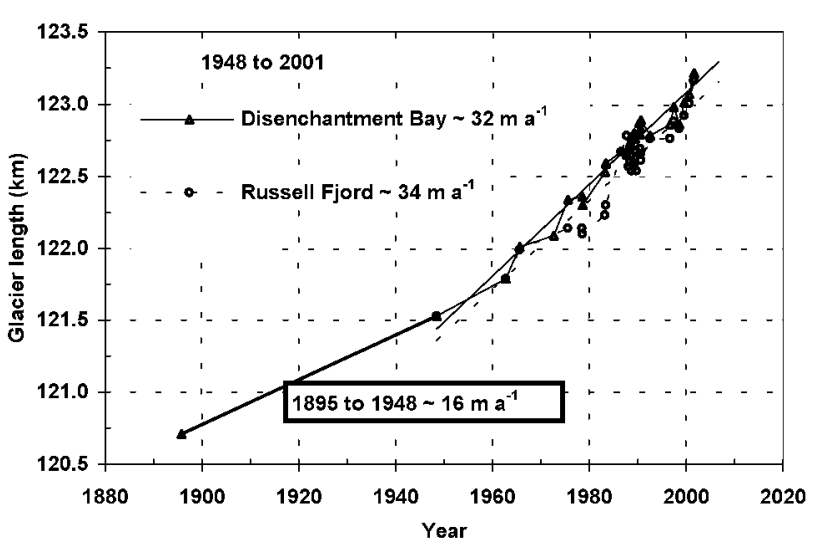

Fig. 6. Width-averaged advance of the termini of Hubbard Glacier since 1895 with linear trends for the period since 1948. The advance rate prior to 1948 was about $16 \mathrm{~m} \mathrm{a}^{-1}$. The linear trends of terminus advance in Disenchantment Bay and Russell Fjord between 1948 and 2001 are about 32 and $31 \mathrm{ma}^{-1}$, respectively.

from systematic changes of the surface strain rate, but no attempt was made to remove the influence of seasonal speed changes from the data, hence the larger scatter. The most recently measured speed near the terminus was $11.5 \mathrm{~m} \mathrm{~d}^{-1}$ during July and August 2001.

Both sets of speed data show somewhat similar rates of deceleration, with the larger rate determined at the fixed location, where surface strain rates decrease as the distance from the calving front increases. The aerial-photograph and satellite-image pairs analyzed for the two datasets are mutually exclusive and therefore independent.

\section{TERMINUS ADVANGE}

The slow, persistent advance of Hubbard Glacier (Figs 6 and 7) has been documented since 1895 by optical surveys, aerial photography and satellite images. The complex shape of the terminus was reduced to a pair of glacier-length values (Figs 6 and 7) by averaging across the widths of the calving faces in Disenchantment Bay and Russell Fjord using the method described in Trabant and others (1991).

A strong seasonal cycle of advance and retreat, and occasional flow instabilities, scatter the spatially averaged lengths (Figs 6 and 7). The seasonal advance (winter to spring) and retreat (summer to fall) can be as large as $100 \mathrm{~m}$ (Trabant and others, 1991). The effects of the 1986 and 1989 pulses of Hubbard Glacier are not evident in this dataset.

The advance of Hubbard Glacier is most accurately represented by the linear trends for long periods because shortperiod averages are adversely influenced by seasonal and pulse-related changes. The 106 year trends for the termini in Disenchantment Bay and Russell Fjord are similar, at about 24 and $23 \mathrm{ma}^{-1}$, respectively. Arbitrarily breaking the set at 1948 reveals acceleration (Fig. 6), from about $16 \mathrm{~m} \mathrm{a}^{-1}$ for both termini prior to 1948 , to about 32 and $31 \mathrm{~m} \mathrm{a}^{-1}$, respectively, after 1948. The 1895-1948 advance was slower because an advance into an increasingly deep fjord requires a large increase in the volume of the terminal moraine to maintain shallow water at the calving face. Since the failure of the temporary dam in 1986, the trend of the advance in Disenchantment Bay has decelerated to a rate of about $28 \mathrm{ma}^{-1}$ (Fig. 7), while the terminus in Russell 


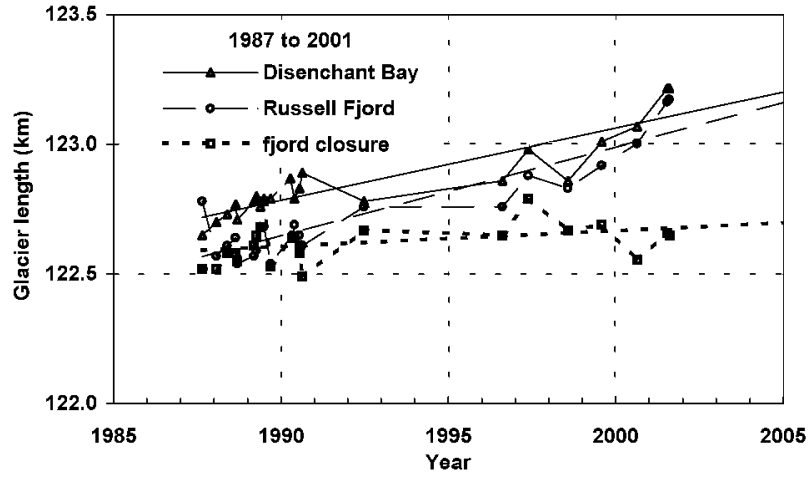

Fig. 7. Advance of Hubbard Glacier since the 1986 dam failed. The linear trend of advance for the 15 year period has decelerated to $28 \mathrm{ma}^{-1}$ in Disenchantment Bay, but changed little for the terminus in Russell Fjord ( $34 \mathrm{~m} \mathrm{a}^{-1}$ ). The advance will close the entrance to Russell Fjord when the glacier length is $123 \mathrm{~km}$ in the fjord closure reach. The linear trend of the advance across the entrance to Russell Fjord since 1986 is about $6 m a^{-1}$.

Fjord continues to advance at a rate of about $34 \mathrm{~m} \mathrm{a}^{-1}$. The trend for the advance across the narrow gap at the entrance to Russell Fjord is about $6 \mathrm{~m} \mathrm{a}^{-1}$. Since the failure of the 1986 dam, the terminus in Disenchantment Bay has advanced $560 \mathrm{~m}$, the terminus in Russell Fjord has advanced $400 \mathrm{~m}$, and the entrance to Russell Fjord has decreased in width by $130 \mathrm{~m}$. On 11 August 2001, the length of Hubbard Glacier at the entrance to Russell Fjord was $122.65 \mathrm{~km}$; the entrance to the fjord will be closed when this length is $123 \mathrm{~km}$.

\section{BATHYMETRY}

Bathymetric data from 1978 and 1999 U.S. National Oceanic and Atmospheric Administration surveys (NOAA, 1978, 1999) were used to evaluate the advance of the submarine terminal moraine in Disenchantment Bay (Fig. 8). Moraine motion was determined by averaging the displacement of a $2.1 \mathrm{~km}$ width of the seaward face of moraine between 120 and $170 \mathrm{~m}$ depths. The average rate of advance was $32 \mathrm{~m} \mathrm{a}^{-1}$. This rate is equal to the 1948-2001 linear trend determined for the calving face.

In Russell Fjord, the calving terminus has been advancing up the stoss slope of a submerged terminal moraine that was identified by Reeburgh and others (1976). It reached the crest of the moraine during 2001. Therefore, bathymetric

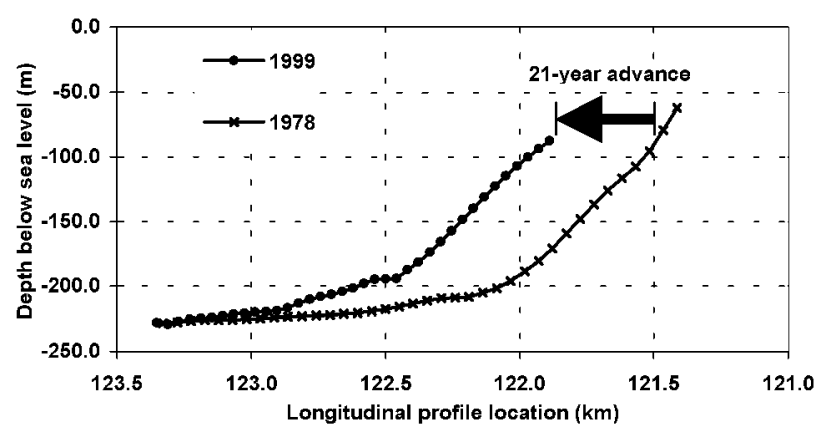

Fig. 8 Bathymetric profiles, 1978 and 1999, on the seaward side of the terminal moraine of Hubbard Glacier. The location of the profiles is shown in Figure 2. analysis of the motion of the moving terminal moraine was not possible. However, the bathymetric data suggest that shoaling near the calving face may have included "bulldozing" of unconsolidated material by the advancing ice. The crest of the old moraine is everywhere $<35 \mathrm{~m}$ below sea level; the shallowest part is $10 \mathrm{~m}$ below sea level.

From 1978 to 2000, the terminus in Disenchantment Bay advanced into areas that had water depths of $150-195 \mathrm{~m}$ in 1988. Near the seaward entrance to Russell Fjord, it advanced from a water depth of $30 \mathrm{~m}$ into an area that had been $23 \mathrm{~m}$ deep in 1988. The terminus in Russell Fjord advanced from $60-80 \mathrm{~m}$ water depths onto the crest of a submerged moraine that is $<35 \mathrm{~m}$ below sea level.

\section{GLIMATE SENSITIVITY}

Hubbard Glacier is not currently sensitive to moderate climate change. Loss of most of its ablation area during 1000 years of retreat prior to the beginning of the current advance left the glacier with an AAR of 0.95 . With $95 \%$ of its surface area in the accumulation zone, the glacier is far from equilibrium with climate, on the positive mass-balance side. Trabant and others (1991) showed that raising the equilibrium-line altitude (ELA) by $200 \mathrm{~m}$ above the current $1000 \mathrm{~m}$ ELA changes the AAR to 0.91. The ELA would have to be raised $1000 \mathrm{~m}$ in altitude before Hubbard Glacier's AAR is reduced to 0.7, where it might begin to be sensitive to climate. It is thus unlikely that global change will have an appreciable influence on the glacier for some time. Furthermore, because Hubbard Glacier is not presently sensitive to climate, the ongoing advance is not representative of how most glaciers are responding to current trends in climate.

\section{DISGUSSION}

The thickening, lateral expansion, and advance of Hubbard Glacier is driven by a positive mass balance and controlled by the rate at which the terminal moraine is moved forward. An estimated $1 \%$ of the mass flux out of the accumulation area goes into storage as the terminal lobe grows, about $4 \%$ is melted, and $95 \%$ is lost by calving (Trabant and others, 1991). The growth of Hubbard Glacier is in sharp contrast with the other glaciers in the area, which have extensive ablation areas, where the ongoing thinning is climatedriven (Arendt and others, 2002).

The recent advance rate of the terminus into Disenchantment Bay is slower than that into Russell Fjord because Disenchantment Bay is as much as seven times as deep as Russell Fjord ( $200 \mathrm{~m}$ vs $30 \mathrm{~m}$ ). The decelerating advance into Disenchantment Bay during the last 15 years is related to both increasing water depth in the fjord and a gradual reduction in the calving flux. The calving flux gradually decreases as the glacier advances and more ice goes into storage and melts.

The advance in the narrow gap at the entrance to Russell Fjord is the slowest measured along the calving face, in spite of the relatively shallow water. This is probably because extreme tidal currents increase the rate of melt and erosion of ice along the narrow passage. The continuing advances in Disenchantment Bay and Russell Fjord effectively increase the length of the tidal channel connecting Russell Fjord with Disenchantment Bay (Fig. 2), which gradually reduces the energy gradient of the flow through the passage. This may decrease the 
effects of melting and erosion along the increasing length of the ice face, effectively reducing the current-induced calving. At some time, the increasing channel length may sufficiently reduce these erosional mechanisms, and a closure of Russell Fjord will occur. The closure in 2002 was similar to the 1986 closure in that glacial-marine sediments were pushed and squeezed until they rose above sea level, forming a dam between the ice and bedrock. A consequence of rising water levels in Russell Lake is the possibility of increased calving and retreat of the terminus in Russell Lake.

Hubbard Glacier is representative of a small number of calving glaciers in Alaska that are in the advancing phase of the calving glacier cycle. Like Hubbard, these glaciers are not sensitive to the ongoing climate changes. In a similar manner, calving glaciers that are in the retreat phase of the calving glacier cycle are not very sensitive to climate. Calving glaciers become sensitive to climate only when the losses due to melting approach an equilibrium with the mass flux out of the accumulation area. That is, sensitivity to climate and loss of an ability to replace calving losses usher in the beginning of the retreat phase.

\section{REFERENGES}

Arendt, A., K. A. Echelmeyer, W. D. Harrison, C. Lingle and V. Valentine. 2002. Rapid wastage of Alaska glaciers and their contribution to rising sea level. Science, 297(5580), 382-386.

Brown, C. S., M. F. Meier and A. Post. 1982. Calving speed of Alaska tidewater glaciers, with application to Columbia Glacier. U.S. Geol. Surv. Prof. Pap. 1258-C.

Davidson, G. 1903. The Alaska boundary. San Francisco, Alaska Packers Association.

de Laguna, F. 1972. Under Mount Saint Elias: the history and culture of the Yakutat Tlingit. Washington, DC, Smithsonian Institution Press. (Smithsonian Contributions to Anthropology 7.)

Echelmeyer, K. A. and 8 others. 1996. Airborne surface profiling of glaciers: a case-study in Alaska. 7. Glaciol., 42(142), 538-547.

Gilbert, G. K. 1904. Glaciers and glaciation. New York, N.Y., Doubleday, Page and Co. (Harriman Alaska Expedition, 1899, Harriman Alaska Series Vol. 3.)

Krimmel, R. M. 2001. Photogrammetric data set, 1957-2000, and bathymetric measurements for Columbia Glacier, Alaska. U.S. Geol. Surv. Water-Resour. Invest. Rep. 01-4089.

Mayo, L. R. 1988. Hubbard Glacier near Yakutat, Alaska: the ice damming and breakout of Russell Fiord/Lake, 1986. U.S. Geol. Surv. Water-Supply Pap. 2325, 42-49.

Mayo, L. R. 1989. Advance of Hubbard Glacier and 1986 outburst of Russell
Fiord, Alaska, U.S.A. Ann. Glaciol., 13, 189-194.

Motyka, R. J. and A. Post. 1995. Taku Glacier: influence of sedimentation, accumulation to total area ratio, and channel geometry on the advance of a fjord-type glacier. In Engstrom, D. R., ed. Third Glacier Bay Science Symposium, 14-18 September 1993. Proceedings. Anchorage, AK, National Park Service, 38-45.

National Oceanic and Atmospheric Administration (NOAA). 1978. National Ocean Service (NOS) Hydrographic survey data on CD-ROM. Boulder, CO, U.S. Department of Commerce. National Oceanic and Atmospheric Administration (NOAA). National Ocean Service (NOS). National Geophysical Data Center (NGDG). (H-09779.)

National Oceanic and Atmospheric Administration (NOAA). 1999. National Ocean Service (NOS) Hydrographic survey data on CD-ROM. Boulder, CO, U.S. Department of Commerce. National Oceanic and Atmospheric Administration (NOAA). National Ocean Service (NOS). National Geophysical Data Center (NGDC). (H-10902.)

Plafker, G. and D. J. Miller. 1958. Glacial features and surficial deposits of Malaspina District, Alaska. U.S. Geol. Surv. Misc. Geol. Invest. 1-271, map. (Scale: $1: 125,000$.

Post, A. 1975. Preliminary hydrography and historic terminal changes of Columbia Glacier, Alaska. U.S. Geol. Surv. Hydrol. Invest. Atlas HA-559, 3 maps (scale $1: 10,000$ ).

Post, A. 1980a. Preliminary bathymetry of Aialik Bay and neoglacial changes of Aialik and Pederson Glaciers, Alaska. U.S. Geol. Surv. Open File Rep. 80-423.

Post, A. 1980b. Preliminary bathymetry of Blackstone Bay and Neoglacial changes of Blackstone Glacier, Alaska. U.S. Geol. Surv. Open File Rep. 80-418.

Post, A. 1980c. Preliminary bathymetry of McCarty Fiord and neoglacial changes of McCarty Glacier, Alaska. U.S. Geol. Surv. Open File Rep. 80-424.

Post, A. 1980d. Preliminary bathymetry of Northwestern Fiord and neoglacial changes of Northwestern Glacier, Alaska. U.S. Geol. Surv. Open File Rep. 80-414.

Post, A. and R.J. Motyka. 1995. Taku and LeConte Glaciers, Alaska: calving-speed control of Late-Holocene asynchronous advances and retreats. Phys. Geogr., 16(1), 59-82.

Reeburgh, W.S., R. D. Muench and R. T. Cooney. 1976. Oceanographic conditions during 1973 in Russell Fjord, Alaska. Estuar. Coastal Mar. Sci., 4, 129-145.

Russell, I. C. 1891. An expedition to Mount St. Elias, Alaska. Nat. Geogr. Mag., 3, 53-204.

Russell, I. C. 1893. Second expedition to Mount St. Elias. In Powell, J.W., ed. Thirteenth Annual Report of the United States Geological Survey to the Secretary of the Interior, 1891-'92: Part II. Geology. Washington, DC, Government Printing Office, 7-91.

Seitz, H. R., D. S. Thomas and B. Tomlinson. 1986. The storage and release of water from a large glacier-dammed lake: Russell Lake near Yakutat, Alaska, 1986. U.S. Geol. Surv. Open File Rep. 86-545.

Tarr, R. S. and L. Martin. 1906. Recent changes of level in the Yakutat Bay region, Alaska. Geol. Soc. Am. Bull., 17, 29-64.

Trabant, D. C., R. M. Krimmel and A. Post. 1991. A preliminary forecast of the advance of Hubbard Glacier and its influence on Russell Fiord, Alaska. U.S. Geol. Surv. Water-Resour. Invest. Rep. 90-4172. 